Apidologie, 1977, 8 (3), 229-235.

\title{
CAGED HONEY BEES (HYMENOPTERA, APIDAE) : COMPARATIVE VALUE OF SOME PROTEINS FOR INITIATING AND MAINTAINING BROOD REARING ${ }^{(1,2)}$
}

\author{
Elton W. HERBERT, Jr., H. SHIMANUKI and Dewey CARON * \\ Bioenvironmental Bee Laboratory, Plant Protection Institute, \\ ARS, USD A, Beltsville, Md. 20705 \\ * University of Maryland, College Park, Md. 20740.
}

\begin{abstract}
SUMMARY
Diets for honey bees, Apis mellifera L., that might substitute for pollen were formulated on the basis of chemical analyses of the essential nutrients in bee bread and pollen from 7 locations. These diets were then fed to newly emerged bees, and the brood-rearing capabilities were determined. A spray-dried brewers' yeast, whey by-products, and pollen were most effectively utilized by the bees for brood rearing, but formulated diets could be made more attractive by the addition of extracts of corn gluten. Bees fed diets fortified with $20 \%$ whey $10 \%$ corn gluten produced significantly more brood than bees fed whey fortified with either 1 or $5 \%$ corn gluten or a pollen diet.
\end{abstract}

Although various materials have been fed to honey bees, Apis mellifica L., as pollen substitutes or as pollen supplements, brood rearing of such colonies has generally been poor compared with that of bees fed fresh pollen. For example, HAYDAK (1936) evaluated the effect of 11 protein sources fed to honey bee colonies by measuring the dry weight and nitrogen content of bee thoraces. Later (HAYDAK 1937), he found that colonies fed soybean flour or mixtures of skim milk powder with cottonseed or soybean meal reared brood normally though the number of sealed cells and larvae was smaller than the number reared by a caged colony fed pollen.

1. Part of a thesis submitted by the senior author in partial fulfillment of the requirements of the Ph. D. degree in Entomology, University of Maryland, College Park. Received for publication.

2. Mention of a proprietary item in this paper does not constitute an endorsment of this product by the USDA. 
After Haydak's pioneering effort, Maurizio (1951) studied the degree of development of the hypopharyngeal glands of newly emerged bees fed 11 diets. Wahl $(1954,1963)$ found that confined colonies could rear brood when fed brewers' yeast, Torula yeast, or soybean flour or dried milk but that the amount was smaller than when colonies were fed bee-collected pollen or bee bread. Also Standifer et al. (1960) measured the gland development and longevity of honey bees fed protein diets and found that many of the sources tested were deficient in 1 or more amino acids. Later Standifer et al. (1970, 1973) evaluated other pollen substitutes but concluded that the biological effectiveness was minor compared with that of fresh pollen. We therefore decided to analyze bee bread and pollen and to formulate substitute diets based on our findings.

Materials and Methods.-Bee bread and pollen from 7 geographic locations in the United States were analyzed for moisture, protein, reducing and nonreducing sugar, starch, amylase activity, lipids, sulfated ash, crude fiber, pectins, and lactic acid. Then diets were formulated that contained $23 \%$ protein, on the basis of this information, by varying the amount of protein added to a basic mixture consisting of sucrose $(30.31 \mathrm{~g})$, cottonseed oil $(5.35 \mathrm{~g})$, $10 \mathrm{ml}$ of a vitamin B mixture * (HAYDAK and DieTz 1965), and enough Alphacel ${ }^{\circledR}$ to make a total of $100 \mathrm{~g}$ (dry weight). Warm water was added until the diet could be worked into a moist patty. This basic mixture was used in all diets except those containing Wheast ${ }^{(\mathbb{B}}$. The Wheast diets did not contain cottonseed oil or the vitamin mixture. The fresh pollen used as the standard was obtained from the pollen traps placed on hives located in the Beltsville USDA apiary.

Candidate diets were fed to colonies housed in small hives (nucs) used for queen mating. The nucs were placed in flight cages $(2 \times 2 \times 2 \mathrm{~m})$ and divided into 2 units so each side consisted of 5 drawn shallow combs $(25 \times 16 \times 20 \mathrm{~cm})$ free of any pollen or honey. Each nuc was stocked with Italian worker bees and a fertile laying queen. The newly emerged workers were obtained by brushing combs of sealed brood taken from standard hives and held in an incubator at $35^{\circ} \mathrm{C}$. The bees were brushed from the combs at $6 \mathrm{~h}$ intervals until each nuc contained $500 \mathrm{~g}$ of bees.

As soon as the nucs were established, $100 \mathrm{~g}$ of a candidate test diet were placed in a plastic petri dish lid $(15 \times 100 \mathrm{~mm})$ and inverted over the frames. Colonies were examined daily, and sugar syrup $(50 \% \mathrm{w} / \mathrm{v})$ and diets were fed twice a week. When the Ist sealed brood appeared the number of sealed cells was estimated with a wire grid of $2.5-\mathrm{cm}^{2}$ divisions. The diet consumption was measured in the 1975 study but not in the 1973-1974 studies.

* The vitamin mixture consisted of the following $\left(\mathrm{g} / 500 \mathrm{ml} \mathrm{H}_{2} 0\right)$; choline chloride 50.000 ; nicotinic acid 18.000 ; calcium pantothenate 2.000 ; thiamine hydrochloride 0.900 ; riboflavin 1.800 ; pyridoxine 0.500 ; folic acid 0.250 ; biotin 0.025 ; inositol 18.000 ; and vitamin $B_{12} 0.002$. 
During the summer of 1973,10 protein sources were tested, Wheast (2 diets), Ralston Purina Dog Chow $^{(\mathbb{R})}$, soybean protein, wheat germ flour, rolled oats, vitamin-free casein, Dadant's Quik-Gro ${ }^{R}$, pollen and bee bread. The Ist Wheast diet contained Wheast alone; the 2nd contained Wheast supplemented with $10 \mathrm{ml}$ of lactic acid which reduced the $\mathrm{pH}$ from 5.2 to 4.1 . In 1974, 12 protein sources were tested : Wheast, pollen, cottonseed meal, corn steepwater, meat and bone meal, Vanderzant's diet, corn gluten meal, soybean meal, whey, Lactobacillus bulgaricus fermented whey, Saccharomyces lactis fermented whey, and Bee Wheast ${ }^{\mathrm{R}}$.

The soybean diet tested in 1973 contained soybean protein $(72 \%)$ extracted from defatted soybean meal by using various solvents. The soybean diet used in 1974 was soybean meal (44\% protein) from which the fats had been removed by a hexane extraction; following the hexane extraction, the meal was steamed at $100{ }^{\circ} \mathrm{C}$ for $15 \mathrm{~min}$ to inactivate the trypsin inhibitors.

In 1975, Nutrex $2.000^{\mathrm{R}}$, a spray-dried yeast (Saccharomyces fragilis) containing $50 \%$ protein, and Yeaco $20^{\mathrm{k}}$, a spray-dried brewer's yeast containing $43 \%$ protein, were compared with pollen and corn gluten. In addition, in an effort to increase the attractiveness of the diets to bees, the diet containing Wheast (34.48 g, $20 \%$ protein) was formulated by mixing with either


The diet containing soybean $(45.45 \mathrm{~g}, 20 \%$ protein) was prepared with $16.66 \mathrm{~g}$ corn gluten (10\% protein).

Results and discussion. - Several of the diets tested during the study that did not support brood rearing were effective in initiating egg laying by queens, but no further development occurred. In other cases, young larvae were observed several times, but none reached the pupal stage. The poor results with these diets may generally be explained by poor consumption and consequent inadequate intake of the nutrients required for minimum growth. We did not measure the diet consumption during the 1973-1974 study, but we felt that the differences in consumption were significant enough to change the outcome of the test.

Table 1 shows the total area $\left(\mathrm{cm}^{2}\right)$ of brood for each diet that supported brood rearing during the studies in 1973 and 1974. In 1973, the consumption of soybean flour protein, rolled oats, and Quik-Gro was poor compared with the consumption of pollen and bee bread. Bees fed Wheast or the Wheast + lactic acid diet reared greater amounts of brood than pollen-fed bees, and there was no significant difference $(P>0.05)$ between the amount of brood reared by bees fed Wheast or Wheast-lactic acid diets. There was also no difference in the nutritive value of bee bread and pollen based on the amount of brood reared. There were 3 diets tested in 1973 that did not support brood rearing, Ralston Purina Dog Chow, wheat germ flour, and vitamin-free 
casein. After 40 days, the nucs fed the dog chow were removed from the test because the population had dwindled severely. The wheat germ-fed bees reared larvae to the 2-to 3 -day-old stage, but none were capped. Diet containing vitamin-free casein was inferior to all other diets. The bees did not consume the diet and apparently maintained themselves on the sugar syrup.

TAB. 1. - Amount of sealed brood ${ }^{a}$ reared by bees fed test diets in $1973^{b}$ and $1974^{c}$

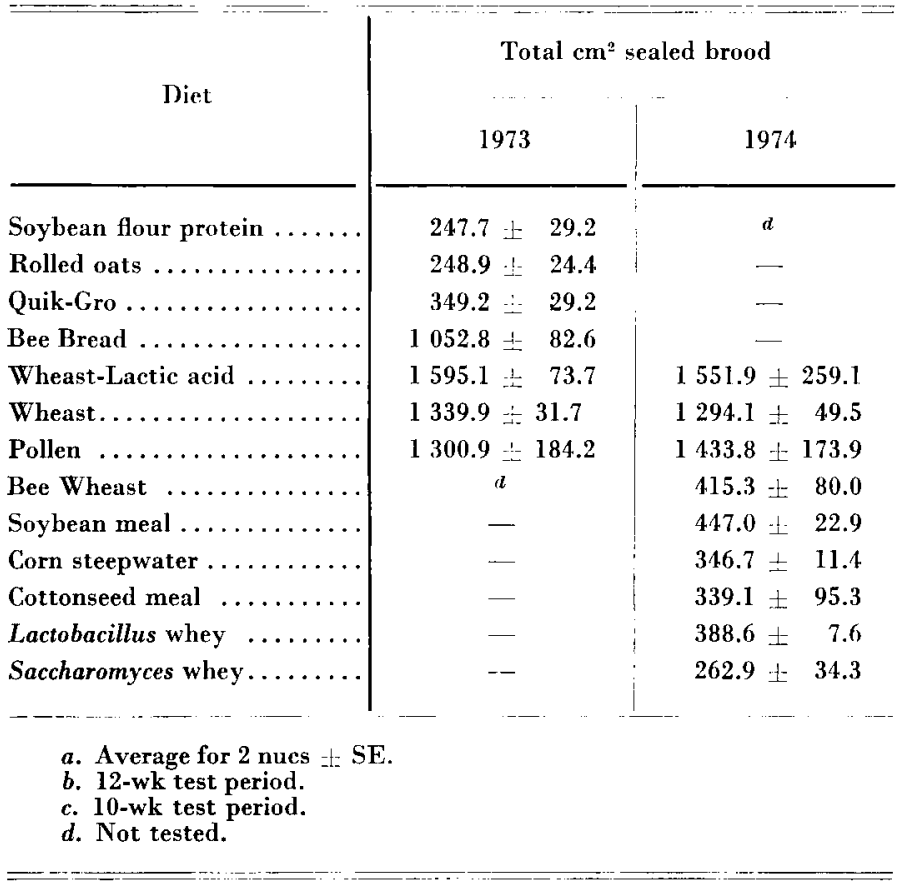

During 1974 (Table 1) bees fed Wheast-lactic acid reared more brood than bees fed any other diet including pollen and continued to rear brood longer. Initially the Lactobacillus whey diet was readily accepted by the bees, but the warm temperatures caused this more moist diet to run between the brood combs. When we tried to overcome the problem by placing a single layer of cheesecloth over the diet before the petri dish was inverted over the frames, consumption was greatly reduced. Bees fed the Saccharomyces whey diet reared less brood than bees fed the Lactobacillus whey diet, probably because $7 \%$ lactose was present after the fermentation of whey by Saccharomyces lactis. Earlier studies (unpublished) have shown that bees are not able to tolerate more than $5 \%$ lactose (the level in Lactobacillus whey was $1 \%$ ). The higher concentration of lactose in the Saccharomyces whey may have caused a substantial decrease in the consumption of this diet. Cottonseed 
meal, corn steepwater, and soybean meal allowed brood rearing, but the levels were substantially lower than those for Wheast or pollen-fed bees.

There were 4 diets tested in 1974 that did not support brood rearing. The whey diet was hygroscopic, was not accepted by the bees, and consequently did not support brood rearing. The corn gluten was readily accepted, but no larvae older than 2-3 days were ever observed in these colonies. Bees fed the meat and bone meal had reared $38 \mathrm{~cm}^{2}$ of brood to the pupal stage during 1 wk, but brood rearing ceased thereafter. Vanderzant's diet was not able to support brood rearing.

In 1975, Yeaco 20, a yeast product, was the most effectively utilized diet (Table 2) though Wheast and pollen-fed bees reared larger number of brood to the sealed stage. Bees fed Bee Wheast had retarded brood rearing probably because of relatively poorer acceptance of the diet. This poor acceptance may have occurred because of high levels of ash. Several of the final washings from the commercial preparation of Bee Wheast were eliminated, which gave levels of ash exceeding $15 \%$ compared with less than $10 \%$ in Wheast. When Bee Wheast was washed in distilled water to reduce the ash level, substantial amounts were removed. Kjeldahl nitrogen determinations showed that the level of protein was not significantly altered, and subsequent consumption was greatly improved. The rate of brood rearing then equalled that of Wheast-fed bees.

ТАВ. 2. - Consumption and amount of sealed brood ${ }^{a}$ reared by bees fed test diets in $1975 .{ }^{b}$

\begin{tabular}{|c|c|c|c|}
\hline Diet & $\mathrm{Cm}^{2}$ sealed brood & Grams diet consumed & $\begin{array}{l}\text { Ratio : } \mathrm{cm}^{2} \\
\text { brood / diet }\end{array}$ \\
\hline Yeaco $20 \ldots \ldots \ldots \ldots \ldots$ & $1195.1 \pm 77.5$ & $606.00 \pm 81.00$ & 1.97 \\
\hline $20 \%$ Wheast-10 \% corn gluten ........ & $1610.4 \pm 137.2$ & $1146.50 \pm 23.50$ & 1.40 \\
\hline 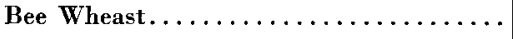 & $1078.2 \pm 138.4$ & $700.50 \pm 52.50$ & 1.54 \\
\hline $20 \%$ Wheast $-5 \%$ corn gluten . . & $1135.4 \pm 15.2$ & $874.00 \pm 24.00$ & 1.29 \\
\hline Wheast $\ldots \ldots \ldots \ldots \ldots \ldots$ & $1205.2 \pm 64.8$ & $798.50 \pm 23.50$ & 1.51 \\
\hline Pollen ............... & $1436.4 \pm 49.5$ & $1155.00 \pm 8.00$ & 1.24 \\
\hline $20 \%$ Wheast-1 $\%$ corn gluten .. & $941.1 \pm 11.4$ & $823.00 \pm 42.00$ & 1.14 \\
\hline $20 \%$ Soybean $-10 \%$ corn gluten & $444.4 \pm 38.1$ & $683.50 \pm 51.50$ & 0.65 \\
\hline $30 \%$ Soybean $\ldots \ldots \ldots \ldots \ldots \ldots$ & $175.3 \pm 2.54$ & $469.50 \pm 51.50$ & 0.37 \\
\hline
\end{tabular}

a. Average for 2 nucs \pm SE.

b. 12-wk test period.

When we mixed protein sources (Wheast or soybean + corn gluten) the brood-rearing capability of newly emerged bees was increased (Table 2). For instance, bees fed the $20 \%$ Wheast-10\% corn gluten diet reared signifi- 
cantly more brood than bees fed. Wheast fortified with either 1 or $5 \%$ corn gluten, pollen or Wheast. Bees fed the $20 \%$ soybean diet supplemented with $10 \%$ corn gluten reared a greater number of bees to the sealed stage; and this diet was consumed in greater quantities than the $30 \%$ soybean diets, although these differences were not significant.

Therefore the diets tested during our 3-year study that successfully supported brood rearing did so generally because of increased consumption that resulted in the intake of adequate levels of the essential nutrients. Diets that did not support brood rearing were consumed in minimum quantities by the bees, probably because of poor consistency. However, some diets may have lacked essential vitamins, amino acids, or other nutrients required by the bees to support brood rearing.

Our test results indicate that bees can utilize many protein sources as pollen substitutes. The most promising based on quantity of brood reared, were those formulated with Wheast or Yeaco 20. Corn gluten appears to be a promising addition that makes diets attractive to bees. In addition, formulations should be prepared so that they can retain the desired consistency despite a variety of temperatures and humidities.

Reçu pour publication en mai 1977.

Eingegangen im Mai 1977.

\title{
Résumé
}

\author{
Comparaison de la valeur de quelques protétines \\ pour le démarrage ET LE MAINTIEN DE L'Élevage de COUVAin \\ CHEZ DES ABEILLES ENCAGÉES
}

Des régimes pour l'abeille, Apis mellifica L., susceptibles de remplacer le pollen ont été mis au point d'après les analyses chimiques des constituants essentiels du pain d'abeille et du pollen, prélevés en 7 endroits différents. On a ensuite nourri avec ces divers régimes des colonies d'abeilles récemment écloses et maintenues en cage. Les régimes suivants, testés en 1973, ont permis l'élevage du couvain : Weast ${ }^{\mathbb{R}}$, acide lactique - Wheast ${ }^{\mathbb{R}}$, protéine de soja, flocons d'avoine, Quik Gro ${ }^{\circledR}$, pollen et pain d'abeille.

En 1974 des abeilles, nourries avec du pollen, du Wheast ${ }^{(\mathcal{R}}$, du Bee Wheast ${ }^{(\bar{R})}$, du petit lait fermenté par Saccharomyces, du petit lait fermenté par Lactobacillus, de la farine de graine de cotonnier, de l'eau de trempage du maïs, de la farine de soja et des germes de blé, ont élevé du couvain avec succès. Au cours de 3 années d'étude, les abeilles nourries au Wheast ont élevé autant de couvain jusqu'au stade operculé que celles nourries au pollen. La consommation des divers régimes, sauf ceux renfermant du Wheast, a été faible par rapport à la consom. mation de pollen et de pain d'abeille.

Le régime testé, qui a été utilisé avec la meilleure efficacité, est le Yeaco $20{ }^{\circledR}$, produit constitué de levure. D'autres études ont montré que l'on pouvait rendre plus attractif les régimes constitués de Wheast en leur ajoutant des extraits de gluten de blé. Les abeilles nour- 
ries avec des régimes renforcés avec $20 \%$ de Wheast et $10 \%$ de gluten de blé ont produit significativement plus de couvain que celles nourries avec des régimes de Wheast renforcés d'I \% ou de $5 \%$ de gluten de blé, ou celles nourries au pollen.

\section{ZUSAMMENFA SSUNG}

\section{VERgleichsWerte EINIgER PROTEINE FÜr DAS AUSLÖSEN UND AUFRECHTERHALTEN DER BRUTTÄTIGKEIT BEI GEKÄFIGTEN hONIGBIENEN (Apis mellifica L.)}

Futter, das als Pollenersatz für Apis mellifica L. dienen könnte, wurde aufgrund chemischer Analysen der wesentlichen Nährstoffe von Bienenbrot und Pollen, der aus sechs verschiedenen Orten stammte, hergestellt. Die Nahrung wurde an gekäfigte Völkchen mit frisch geschlüpften Bienen verfüttert und deren Fähigkeit, Brut aufzuziehen, untersucht. Mit den folgenden, 1973 überprüften verschiedenen Futtergaben war es möglich, die Bruttätigkeit aufrechtzuerhalten Wheast ${ }^{(\mathbb{B})}$, Milchsäure-Wheast, Sojabohnen-Eiweiss, Haferflocken, Quik-Gro(B), Pollen und Bienenbrot.

1974 zogen Bienen, die mit Pollen, Wheast, Bienen-Wheast, mit Lactobacillus fermentierter Molke, mit Saccharomyces fermentierter Molke, Baumwollkuchenmehl, Einweichwaaser von Mais, Sojamehl und Weizenkeimen gefüttert wurden, erfolgreich Brut auf. Während der drei Jahre dauernden Versuche zogen mit Wheast gefütterte Bienen ebensoviel Brut bis zum Verdeckeln auf wie mit Pollen ernährte Bienen. Der Verbrauch aller Futtermittel, ausgenommen die, die Wheast enthielten, war gering im Vergleich zum Pollen- und Bienenbrot-Verzehr.

Yeaco 20 R, ein Hefeprodukt, wurde von den überprüften Mitteln am wirksamsten genutzt. Zuzätzliche Untersuchungen zeigten, dass Wheast-Futter durch Zusatz von Extrakten aus Mais-Gluten anziehender für die Bienen gemacht werden kann. Bienen, denen mit $10 \%$ Wheast-10\% Mais-Gluten angereichertes Futter geboten wurde, zogen bedeutend mehr Brut auf als Bienen, die Wheastkost erhielten, die mit nur $1 \%$ oder $5 \%$ Mais-Gluten angereichert war oder als Bienen, die mit Pollen gefüttert wurden.

\section{REFERENCES}

HAYDAK M. H., 1936. - Value of foods other than pollen in nutrition of the honey bee. J. Econ. Entomol., 29, 870-6.

HaYdak M. H., 1937. - Further contribution to the study of pollen substitutes. J. Econ. Entomol., $30: 637-42$.

HAYDAK M. H., Dietz A., 1965. - Influence of the diet on the development and brood rearing of honey bees. Proc. XV Intl. Beekeeping Congr., Bucharest. 1965, 1-6.

Maurizio A., 1951. - Tests of pollen substitutes. Schweiz. Bienenztg. 74, 111-8.

Standifer L. N., Haydak M. H., Mills J. P., Levin M.D., 1973. - Value of three protein rations in maintaining honey bee colonies in outdoor flight cages. $J$. Apic. Res., 12, 137-43.

Standifer L. N., MacDonald R. H., Levin M. D., 1970. - Influence of the quality of protein in pollens and of a pollen substitute on the development of the hypopharyngeal glands of honey bees. Ann. Entomol. Soc. Amer., 63, 909-10.

Standifer L. N., McCaughey, W. F. Tood F. E., Kemmerer A. R., 1960. - Relative availability of various proteins to the honey bee. Ann. Entomol. Soc. Amer., 53, 618-25.

$W_{A H L} 0 ., 1954$. - Investigations on the food value of pollen substitutes for the honey bee. Insectes Soc., 1, 285-92.

WAHL O., 1963. - Comparative investigations on the food value of pollen, yeast, soybean flour and dried milk for the honeybee (Apis mellifera L.). Z. Bienenforsch., 6, 209-280. 